\title{
The Synthesis of Organoclays Based on Clay Minerals with Different Structural Expansion Capacities
}

\author{
Leonid Perelomov ${ }^{1}\left(\mathbb{D}\right.$, Saglara Mandzhieva ${ }^{2, *} \mathbb{C}$, Tatiana Minkina ${ }^{2} \mathbb{D}$, Yury Atroshchenko ${ }^{1}$, Irina Perelomova ${ }^{3}$, \\ Tatiana Bauer ${ }^{4}$, David Pinsky ${ }^{5}$ and Anatoly Barakhov ${ }^{2}$ \\ 1 Faculty of Natural Sciences, Tula State Lev Tolstoy Pedagogical University, 300026 Tula, Russia; \\ perelomov@rambler.ru (L.P.); reaktiv@tsput.ru (Y.A.) \\ 2 Academy of Biology and Biotechnology, Southern Federal University, 344006 Rostov-on-Don, Russia; \\ tminkina@mail.ru (T.M.); tolik.barakhov@mail.ru (A.B.) \\ 3 Faculty of Medicine, Tula State University, 300026 Tula, Russia; ketava@rambler.ru \\ 4 Federal Research Center "Southern Scientific Center of the Russian Academy of Sciences", Chekhov Street, \\ 344006 Rostov-on-Don, Russia; bauertatyana@mail.ru \\ 5 Institute of Physicochemical and Biological Problems in Soil Science of the Russian Academy of Sciences, \\ Institutskaya Street, 2, 142290 Pushchino, Russia; pinsky43@mail.ru \\ * Correspondence: msaglara@mail.ru; Tel.: +7-988-896-95-53
}

Citation: Perelomov, L.; Mandzhieva, S.; Minkina, T.; Atroshchenko, Y.; Perelomova, I.; Bauer, T.; Pinsky, D.; Barakhov, A. The Synthesis of Organoclays Based on Clay Minerals with Different Structural Expansion Capacities. Minerals 2021, 11, 707. https://doi.org/10.3390/min11070707

Academic Editor: Yuri Lopes Zinn

Received: 16 May 2021

Accepted: 28 June 2021

Published: 30 June 2021

Publisher's Note: MDPI stays neutral with regard to jurisdictional claims in published maps and institutional affiliations.

Copyright: (c) 2021 by the authors. Licensee MDPI, Basel, Switzerland. This article is an open access article distributed under the terms and conditions of the Creative Commons Attribution (CC BY) license (https:/ / creativecommons.org/licenses/by/ $4.0 /)$.

\begin{abstract}
An important goal in environmental research for industrial activity and sites is the investigation and development of effective adsorbents for chemical pollutants that are widespread, inexpensive, unharmful to the environment, and have the required adsorption selectivity. Organoclays are adsorption materials that can be obtained by modifying clays and clay minerals with various organic compounds through intercalation and surface grafting. Organoclays have important practical applications as adsorbents of a wide range of organic pollutants and some inorganic contaminants. The traditional raw materials for the synthesis of organoclays are phyllosilicates with the expanding structural cell of the smectite group, such as montmorillonite. Moreover, other phyllosilicates and inosilicates are used to synthesize organoclay to a limited extent. The purpose of this review was to analyze the possibility of using minerals of other groups with different abilities to expand the structure and structural charge for the adsorption of chemical environmental pollutants. The structural characteristics of various groups of phyllosilicates and chain minerals that affect their ability to modify organic surfactants and the adsorption properties of prepared organoclays were reviewed.
\end{abstract}

Keywords: anthropogenic pollution; clay mineralogy; environmental technology; intercalation; adsorption

\section{Introduction}

The properties of phyllosilicate (layered) clay minerals, such as great specific surface area, chemical stability, variable expansibility, reactive functional groups, and surface charge make them perfect adsorbents for a wide range of environmental pollutants [1-3]. The advantages of clays as adsorbents are also related to the following: they are naturally widespread, commonly nontoxic, easily mined, and relatively cheap materials. For example, more than $16 \mathrm{Mt}$ of bentonite clays and $44 \mathrm{Mt}$ of kaolin clays are mined annually at present [4]. The price of clay is $0.05-0.46 \mathrm{USD} / \mathrm{kg}$, and the cost of montmorillonite is about 0.04-0.12 USD/kg, which is 20 times cheaper than activated coal $[5,6]$.

Most clay minerals' outer and inner surface is hydrophilic and polar, resulting in high affinities towards low and high-molecular, mainly cationic, substances. However, their anionic substance-adsorbing capacity is low: less than $5 \mathrm{cmol} / \mathrm{kg}$ for smectites [7] and not more than $2 \mathrm{cmol} / \mathrm{kg}$ for kaolinites [8]. Although clay minerals have a hydrophile surface, their significant area and volume of small pores allow the clays to adsorb some 
amount of the nonionogenic substances [9]. The modification of natural clays by organic surface-active substances (surfactants) makes it possible to refine their pore structure and impart the hydrophobic property to their surface if necessary.

The synthesis of special organo-mineral materials (organoclays) by intercalation or by grafting organic surfactants into expanding clay minerals has attracted a great deal of attention over the past two decades [10]. Organoclays have important practical applications as adsorbents of organic pollutants [11,12] and as components in the formation of clay polymer nanocomposites [13]. The theoretical basics for intercalating surfactants into the interlayer space of clay minerals are well understood $([10,12,13]$ etc.). The ability for modification and the resulting organoclays' sorption characteristics are influenced by the properties of the original clay mineral and the properties of the intercalated organic matter. Recently, there has been growing interest in the synthesis of organoclays using zwitterionic substances that form complex adsorption positions and nonionic surfactants with low toxicity and biodegradability $[10,14]$.

Most studies on the synthesis and analysis of the properties of organoclays are focused on the swelling 2:1 structure clay minerals of the smectite group. In this context, the features of surfactant interactions with other groups of clay minerals and organoclays properties remain insufficiently studied. Moreover, some of these organoclays may have unique properties, such as significant adsorption capacity and selectivity to certain types of pollutants. This issue is especially relevant for territories with deposits of phyllosilicates other than montmorillonite and chain silicates. Our review describes the sorption properties of organoclays based on clay minerals with different capacities of expansion and surface charge relative to a wide range of chemical pollutants.

\section{Organoclays and Their Properties}

The idea of using the intercalation technique for the transformation of clays into porous analogs emerged in the 1950s. Barrer and MacLeod studied the adsorption of montmorillonite and the mineral intercalation of various gases and vapors [15]. In 1955, they wrote that the substitution of exchange inorganic cations in montmorillonite by cations $\mathrm{N}\left(\mathrm{CH}_{3}\right)^{4+}$ and $\mathrm{N}\left(\mathrm{C}_{2} \mathrm{H}_{5}\right)^{4+}$ increases the interlayer distance and provokes great changes in the sorption of organic molecules. They also demonstrated sorption selectivity based on the molecular diameter of the cross-section of adsorbates [16].

Organoclays are formed during the intercalation of layered silicates by organic substances not leading to their exfoliation. Organoclays can be defined as clay minerals (phyllosilicates, less commonly, inosilicates) modified by the adsorption of molecules of organic surfactants and/or other substances that retain their layered or chain mineral structure $[17,18]$. Organic-modified smectites synthesized by substituting inorganic counterions for the short-chain compact cationic compounds, such as tetramethylammonium, tetraethylammonium, and trimethylphenylammonium, are defined by some researchers as organoclay adsorbers $[17,19]$. Organic modified minerals obtained by the intercalation of long-chain quaternary ammonium ions of the general form $\left[\left(\mathrm{CH}_{3}\right)_{3} \mathrm{NR}\right]^{+}$or $\left[\left(\mathrm{CH}_{3}\right)_{2} \mathrm{NR}\right]^{+}$, where $\mathrm{R}$ is the alkyl hydrocarbon, are called organophilic organoclays [19]. The substitution of primary interlayer cations by organic cations produces a surface composed of covalent-bonded organic fragments. At the same time, the hydrophile property of the surface can be retained and the hydrophobic or amphiphilic surface can also be formed. In this condition, a significant expansion of the range of potential sorbates can be obtained. In recent years, researchers have devoted much attention to the application of organoclays for the immobilization of various pollutants in soils and clays, as well as the purification of wastewaters $[3,17,18]$. In addition, organoclays can be widely used as fillers in polymer-clay nanocomposites, thereby improving the properties of these materials [13]

The adsorption efficiency of organoclays is governed mainly by the following properties: the presence or absence of defects in the crystal lattice, a cation composition of the interlayer surfaces and a cation exchange capacity of the mineral used for the synthesis of 
organoclays, as well as properties of the intercalated organic substance (molecular mass, length, and the presence of functional groups in the molecule) and its amount.

If the initial mineral has crystal lattice defects, such as bends and fractures in the octahedral and tetrahedral sheets, microfissures, or convex or concave surfaces, the close packing is distorted. As a result, a negative effect on the quality of organoclays would be found due to changes in the homogeneous distribution of the organic substances' molecules. [20]. However, flat defects in crystal structures and point and linear defects (dislocations) in crystals govern the ion adsorption capacity of the initial clay minerals significantly [20]. According to Lagaly (1994) [21], charge heterogeneity is a characteristic property of 2:1 clay minerals (smectite, in particular). In these minerals, charge density can vary in different layers or even within individual sheets; charges are likely to be distributed more uniformly at the centers of clay particles than at the edges [22]. Structure defects in minerals and, correspondingly, the heterogeneity of charge distribution promote a local aggregation of organic substances in such sectors and provoke the expansion and exfoliation of minerals under heavy loads of the intercalated substance. Thus, the charge value and its distribution are important characteristics of the natural mineral. For example, vermiculite has a higher surface charge among the 2:1 phyllosilicates than smectite, and it shows a more uniform and regular structure expansion during treatment with organic cations [22]. Various cation substitutions in the 2:1 structure phyllosilicate layers generate a constant structural charge near the basal plane. Even an ideal pyrophyllite structure (without any regular structural charge) retains the electric field near the basal plane [23].

The most prominent ions on the clay interlayer space are $\mathrm{Ca}^{2+}, \mathrm{Mg}^{2+}, \mathrm{H}^{+}, \mathrm{Na}^{+}, \mathrm{K}^{+}$, $\mathrm{NH}^{4+}, \mathrm{Li}^{+}, \mathrm{SO}_{4}{ }^{2-}, \mathrm{Cl}^{-}, \mathrm{PO}_{4}{ }^{3-}$, and $\mathrm{NO}_{3}{ }^{-}$. These ions can be exchanged relatively easily with other ions, without any influence on the clay mineral structure [2]. The cation composition of smectites depends on the mineral deposit type. The formation of Naand Ca-montmorillonites is governed by the paleogeographic sedimentation settings. Thalassogenic basins with saline and brine $(\mathrm{Na}-\mathrm{Cl})$ waters are marked by the fixation of $\mathrm{Na}$ and $\mathrm{K}$ on clay particles; continental fresh-water basins are marked by the precipitation of alkaline earth elements ( $\mathrm{Ca}$ and $\mathrm{Mg}$ ) [24]. Bivalent cations guarantee a stronger bond between layers relative to the monovalent species. Therefore, bentonite dominated by exchange cations of $\mathrm{Ca}$ (Ca-bentonite) is characterized by a lower dispersion and expansion degree (8-fold structure expansion) than Na-bentonite (15-fold expansion) (Figure 1 [25]). At the same time, the interlayer distance varies from 1-5 nm (for Ca-montmorillonite) to 15-20 nm (for Na-montmorillonite) [24]. The ion charge also affects the ion exchange kinetics. Commonly, the exchange rate shows a negative correlation with the charge of the exchange species [26].

Depending on the properties of the mineral and intercalated substance, the organoclays can be formed with the involvement of electrostatic and ion-dipole interactions, hydrogen bonds, and Van der Waals forces [17]. The charge in the basal layer surface is responsible for the expansion and ion sorption by the cation exchange mechanism. In contrast, the $\mathrm{pH}$-dependent adsorption of cations is controlled by the protonation/deprotonation reactions at the layer edges. The chemical structures of the most commonly used surfactants for the modification of layered silicates are shown in Table 1 [27]. 


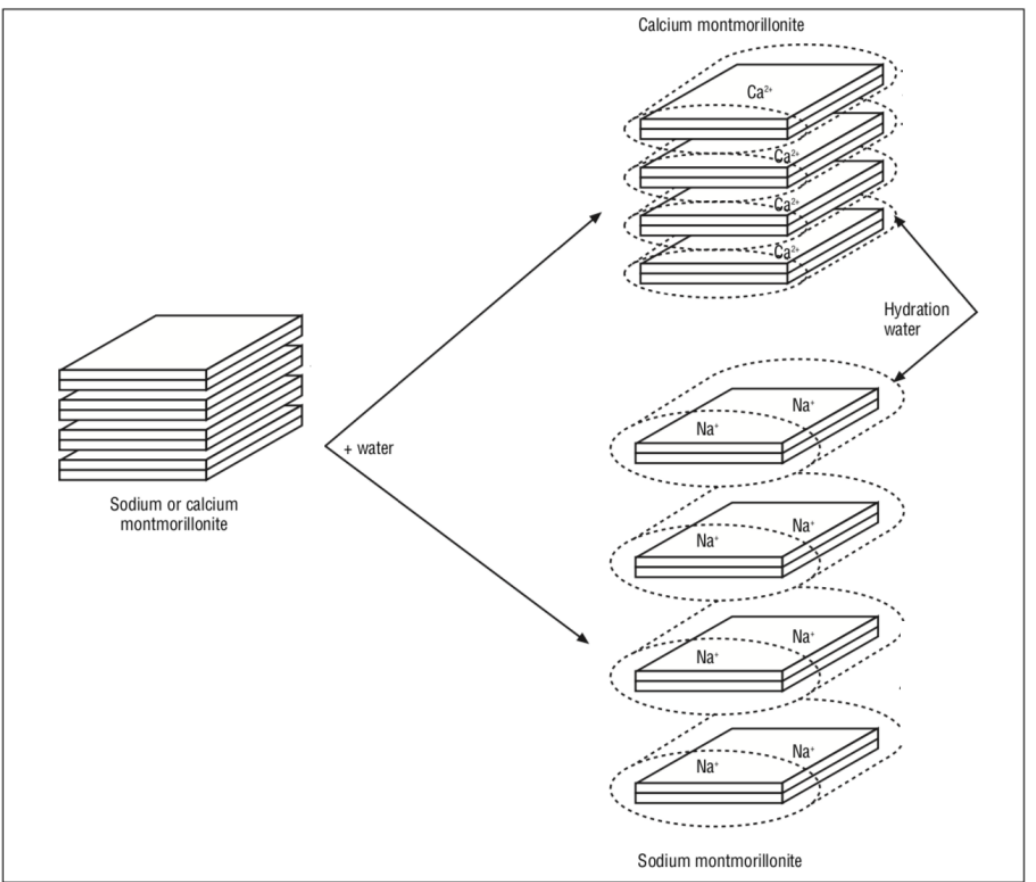

Figure 1. Swelling of Ca-montmorillonite and Na-montmorillonite in water [25].

Table 1. Chemical structures of the most commonly used surfactants for the modification of layered silicates [27].

\begin{tabular}{cccc}
\hline Surfactants & Chemical Formula & Surfactants & Chemical Formula \\
$\begin{array}{c}\text { Methyl tallow } \\
\text { bis-2-hydroxyethyl quaternary } \\
\text { ammonium }\end{array}$ & $\mathrm{H}_{3} \mathrm{C}-\mathrm{N}_{+}-\mathrm{HT}$ & $\begin{array}{c}\text { Polyoxy propylene methyl } \\
\text { diethyl ammonium }\end{array}$ & $\mathrm{CH}_{2} \mathrm{CH}_{2} \mathrm{OH}$
\end{tabular}

Dimethyl dehydrogenated tallow quaternary ammonium

$\left.\left.\right|_{\mathrm{HT}} ^{\mathrm{HT}_{3}}\right|_{\mathrm{NT}} ^{\mathrm{CH}_{3}}-$ Octadecyl amine

\begin{tabular}{|c|c|c|c|}
\hline $\begin{array}{l}\text { Dimethyl dehydrogenated } \\
\text { tallow 2-ethylhexyl } \\
\text { quaternary ammonium }\end{array}$ & $\left.\right|_{\mathrm{HT}^{+}} ^{\mathrm{CH}_{3}}$ & Dimethyl octadecyl amine & $\mathrm{CH}_{3}\left(\mathrm{CH}_{2}\right)_{16} \mathrm{CH}_{2}-\left.\right|_{\mathrm{CH}_{3}} ^{\mathrm{H}}-\mathrm{CH}_{3}$ \\
\hline $\begin{array}{c}\text { Dimethyl benzyl } \\
\text { hydrogenated tallow } \\
\text { quaternary ammonium }\end{array}$ & $\mathrm{CH}_{3}-\left.\right|_{\mathrm{HT}} ^{\mathrm{NT}_{3}-}-\mathrm{CH}_{2}-\mathrm{Ph}$ & $\begin{array}{l}\text { Hexadecyl trimetyl } \\
\text { ammonium }\end{array}$ & $\mathrm{CH}_{3}\left(\mathrm{CH}_{2}\right)_{14} \mathrm{CH}_{2}-\left.\right|_{\mathrm{CH}_{3}} ^{\mathrm{N}^{+}}-\mathrm{CH}_{3}$ \\
\hline $\begin{array}{l}\text { Dimethyl dialkyl (tallow, } \\
\text { presented by T) ammonium }\end{array}$ & $\mathrm{CH}_{3}-\left.\right|_{\mathrm{CH}_{3}} ^{\mathrm{N}+-} \mathrm{T}$ & $\begin{array}{l}\text { Dodecyl triphnyl } \\
\text { phosphonium }\end{array}$ & $\left.\right|_{\mathrm{Ph}} ^{\mathrm{Ph}}-\mathrm{CH}_{2}\left(\mathrm{CH}_{2}\right)_{10} \mathrm{CH}_{3}$ \\
\hline Trioctyl methyl ammonium & $\mathrm{CH}_{3}-\left.\right|_{\mathrm{C}_{8} \mathrm{H}_{17}} ^{\mathrm{N}_{+}}-\mathrm{C}_{8} \mathrm{H}_{17}$ & $\begin{array}{l}\text { Hexadecyl tributyl } \\
\text { phosphonium }\end{array}$ & $\mathrm{CH}_{3}\left(\mathrm{CH}_{2}\right)_{4} \mathrm{CH}_{2}-\left.\right|_{\mathrm{C}_{4} \mathrm{H}_{9}} ^{\mathrm{C}_{4} \mathrm{H}_{9}}-\mathrm{C}_{4} \mathrm{H}_{9}$ \\
\hline
\end{tabular}


Table 1. Cont.

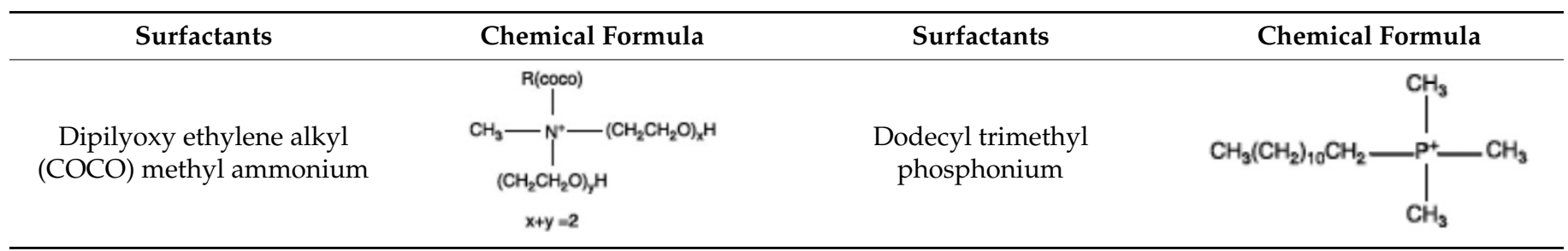

The orientation of intercalated organic molecules with short alkyl chains is governed mainly by the electrostatic interactions of their polar groups with silicate layers. In contrast, compounds with a longer chain interact with the mineral surface via Van der Waals forces. The retention of the adsorbed molecules depends on the polarizing capacity of the interlayer cations. Multivalent cations with a strong electrostatic force can retain a large number of organic compounds relative to alkali metal ions and $\mathrm{NH}_{4}{ }^{+}$[28]. The softness or hardness of exchange cations in the interlayer space governs the coordination bond type in the aliphatic and aromatic amines. Soft cations, such as $\mathrm{Zn}^{2+}, \mathrm{Cd}^{2+}, \mathrm{Cu}^{2+}, \mathrm{Ag}^{+}$, and others, bind the amines directly, whereas water bridges are formed between amines and rigid cations (alkali and alkali earth metal ions) [29]. For example, pyridine is coordinated directly with $\mathrm{Cu}$ ions, but via water bridges with the interlayer $\mathrm{Mg}$ and $\mathrm{Ca}$ cations [30].

The efficiency of adsorption by organoclays is also affected by the presence of associated ions. For example, if electrolytes $(\mathrm{NaCl})$ are present, both nonionic (in general, neutral) and cationic organoclays demonstrate a decrease of efficiency for the adsorption of several pharmaceutical substances (except the cationic ones). In contrast, the adsorption proceeds successfully in water [31].

The chemical affinity between the organic compound and mineral surface depends on the structure (molecular mass, chain length, and others) of organic molecules, as well as the functional groups and fragments in the organic molecule, such as hydrophobic groups (long-chain aliphatic), positively charged groups $\left(-\mathrm{NH}_{3}{ }^{+}\right)$, negatively charged groups $\left(-\mathrm{COO}^{-}\right.$, phenolates, $\left.-\mathrm{SO}_{3}{ }^{-}\right)$, electronegative groups, $(-\mathrm{C}=\mathrm{O},-\mathrm{C}-\mathrm{O}-\mathrm{C}-,-\mathrm{OH}), \pi-$ bonds (-C-C-, aromatic rings), the configuration of the available organic molecule, and the presence and properties of the water phase [32].

Organic substances with one aliphatic chain or flat arrangement of molecules make up one or two layers parallel to the mineral surface [18,33] (Figure 2 [18]). This is exemplified by flat intercalations of aliphatic acids [34]. A stable monolayer structure is obtained if the alkylammonium cation concentration is similar to the cation exchange capacity of the mineral, that is, the cation area is smaller than one exchange site [35]. If the concentration of organic substance increases [18] or the area occupied by the organic cation exceeds the exchange site area [35], two- and three-layer arrangements of the aliphatic chains can appear. The length of the aliphatic chain needed for the monolayer-to-bilayer transition is also affected by the value and distribution uniformity of charge on the silicate surface. If the phyllosilicate has a homogenous charge, the transition can take place abruptly and is characterized by an identical chain length. The interlayer charge, however, usually changes. Therefore, the transitions take place at different numbers of carbon atoms (from 6 to 13) in the chain $[18,22,35]$.

Long-chain ions of alkylammonium and quaternary ammonium can display a pseudothree-layer arrangement (Figure 2), that is, the positive surface-active groups are tied to the silicate layers, while the alkyl chains accept the trimolecular arrangement with bends. In the case of high-charge smectites and vermiculites, the interlayer organic cations can accept the paraffin-type arrangement at a certain angle to the mineral surface [18,36] (Figure 2). This is also fostered by the presence of several long aliphatic chains in the molecule [35]. The intercalation of the long-chain alkylammonium cations provides the penetration of other monomers (and polymers) into the interlayer space [35]. 
A

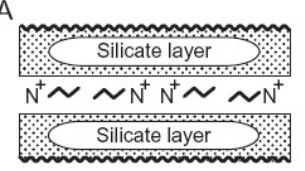

C

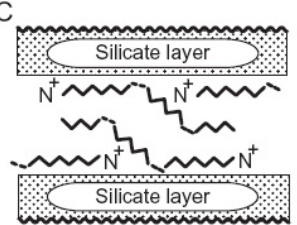

B

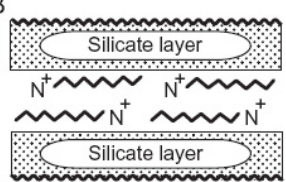

D

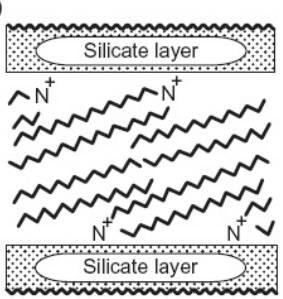

E

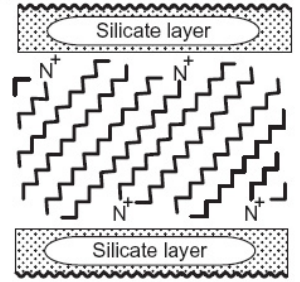

Figure 2. Arrangement of alkylammonium ions in the interlayer space of smectites: (A) monolayers, (B) bilayers, (C) pseudo-trimolecular layers, (D,E) paraffin type arrangements with different tilting angles of the alkyl chains [18].

Several linear nonionic polymers can penetrate the interlayer space only when the clay mineral is dispersed in polymers' waters or organic solvents of polymers. Some macromolecules of technical significance intercalate from the water solutions. Many polymers are intercalated along more extended and flat conformations and situated in tight contact with one or two silicate layers. The unfolding of polylisine and polyglutamine acid during the intercalation in montmorillonite is described by Gougeon et al. [37]. The preference of chains over loops is related to the Van der Waals interaction between the polymer segments and surface oxygen atoms. In contrast to the polymer adsorption on the outer surface, the interlayer adsorption is marked by the active involvement of the molecules with a lower molecular mass [35].

The relationship between the spatial arrangement of organic molecules during the intercalation versus the mineral charge and carbon chain length is demonstrated in Figure 3 [38].

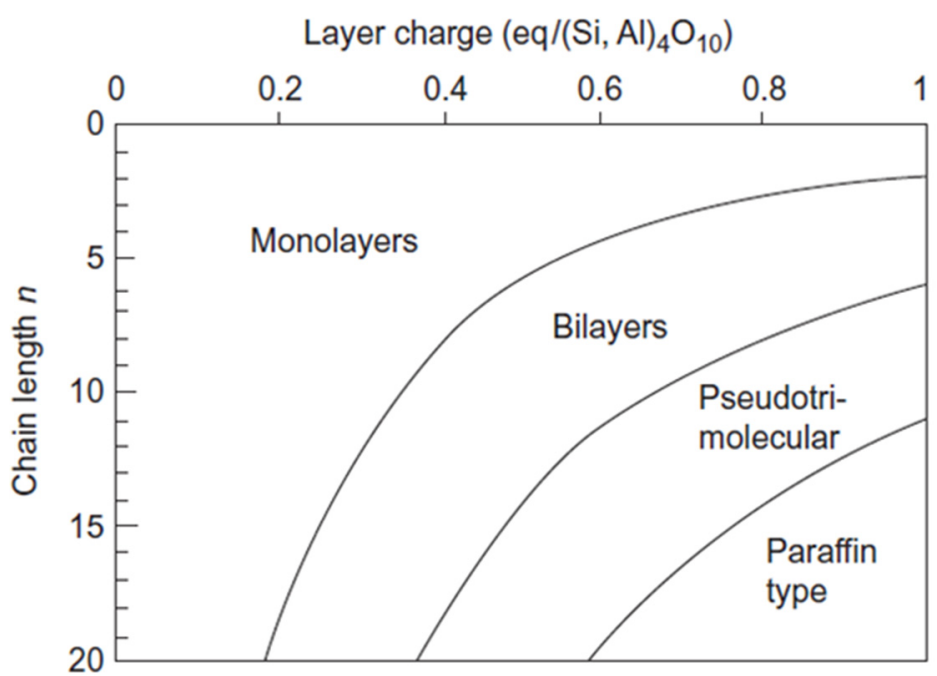

Figure 3. Influence of the layer charge and length of the alkyl chain on the position of alkylammonium ions in the interlayer space [38].

\section{Organoclays Based on Clay Minerals with Different Structure Expansion and Surface Charge Capacities}

The $\mathrm{Si}-\mathrm{O}$ tetrahedra/ $\mathrm{Al}-\mathrm{OH}$ octahedra ratio in the clay mineral structure and the bond strength between silicate layers, which depends mainly on the layer charge, govern, to a significant extent, the specific surface areas of minerals and their cation exchange capacity and, consequently, the adsorption properties of organoclays synthesized on their basis. Based on 
these parameters, layered silicates are divided into several groups (Table 2) [39]. However, $70 \%$ of all clays in deposits have an intricate composition because of the simultaneous presence of several phyllosilicates with a prevalence of one or several minerals [40].

Table 2. Classification of clay minerals based on the $\mathrm{Si}-\mathrm{O}$ tetrahedra/Al-OH octahedra ratio and the surface charge layer [39].

\begin{tabular}{|c|c|c|c|c|}
\hline $\begin{array}{l}\text { Mineral Structure } \\
\text { (Layer Types) }\end{array}$ & $\begin{array}{l}\text { Charge per } \\
\text { Formula Unit }\end{array}$ & Groups & Subgroups & Species Examples \\
\hline \multirow{2}{*}{$1: 1$} & \multirow{2}{*}{0} & \multirow{2}{*}{ Kaolin-Serpentine } & Kaolinite & Kaolinite, dickite, nacrite \\
\hline & & & Serpentine & Chrysotile, lizardite, amesite \\
\hline \multirow{10}{*}{$2: 1$} & \multirow{2}{*}{0} & \multirow{2}{*}{ Talc-Pyrophyllite } & Talc & Talc \\
\hline & & & Pyrophyllite & Pyrophyllite \\
\hline & \multirow{2}{*}{$0.2-0.6$} & \multirow{2}{*}{ Smectite } & Montmorillonite & $\begin{array}{c}\text { Montmorillonite, beidellite, } \\
\text { nontronite }\end{array}$ \\
\hline & & & Saponite & Saponite, laponite, hectorite \\
\hline & \multirow{2}{*}{$0.6-0.9$} & \multirow{2}{*}{ Vermiculite } & Dioctahedral & Dioctahedral vermiculite \\
\hline & & & Trioctahedral & Trioctahedral vermiculite \\
\hline & \multirow[t]{2}{*}{1} & \multirow[t]{2}{*}{ Mica } & Dioctahedral & $\begin{array}{l}\text { Muscovite, illite, glauconite, } \\
\text { paragonite }\end{array}$ \\
\hline & & & Trioctahedral & Phlogopite, biotite, lepidolite \\
\hline & \multirow{2}{*}{2} & \multirow{2}{*}{ Brittle mica } & Dioctahedral & Margarite \\
\hline & & & Trioctahedral & Clintonite, anandite \\
\hline \multirow{3}{*}{$2: 1: 1$} & \multirow{3}{*}{ Variable } & \multirow{3}{*}{ Chlorite } & Dioctahedral & Donbassite \\
\hline & & & Trioctahedral & $\begin{array}{c}\text { Chlinochlore, chamosite, } \\
\text { nimite }\end{array}$ \\
\hline & & & Di, trioctahedral & Cookeite, sudoite \\
\hline \multirow{3}{*}{$\begin{array}{l}\text { Other silicates (close } \\
\text { to inosilicates) }\end{array}$} & \multirow{3}{*}{0.1} & \multirow{3}{*}{ Palygorskite-Sepiolite } & Dioctahedral & Nepouite \\
\hline & & & Palygorskite & Palygorskite \\
\hline & & & Sepiolite & Sepiolite \\
\hline
\end{tabular}

\subsection{Organoclays Based on 1:1 Structure Phyllosilicates}

Since the kaolinite group minerals cannot expand, their utilization as a matrix for synthesizing organoclays is limited. The cation exchange capacity of kaolinite varies from 1 to $10 \mathrm{mg}$ equiv/100 $\mathrm{g}$ for a small area of the specific surface $\left(7-30 \mathrm{~m}^{2} / \mathrm{g}\right)$ [41]. Among the clay minerals of the 1:1 groups, only minerals of the kaolinite subgroup interact with various organic molecules, and serpentines are inactive [13]. The grafted substances can be divided into three groups: (1) substances making up hydrogen bonds (hydrazine, carbamide, and formamide); (2) substances with a high dipole moment (dimethyl sulfoxide and pyridine-Noxide); (3) potassium, rubidium, cesium, and ammonium salts of short-chain aliphatic acids (acetates, propionates, butirates, and isovalerates). The mechanism of their interaction with kaolinite is not clear [18]. Nevertheless, kaolinite clays are used for the synthesis of organoclays because they are widespread and cheap. The synthesis of organoclays is accomplished by the soft chemical treatment method, particularly by aggregation during the melting of alkylammonium ionic liquids. Alkylammonium salts with a short alkyl chain are grafted directly by melting at $180^{\circ} \mathrm{C}$ in a nitrogen atmosphere when they replaced dimethyl sulfoxide (DMSO), preliminarily attached to kaolinite. Inoculation for longer alkyl chains is accomplished in two stages. In the first stage, the corresponding amino alcohol is attached to kaolinite by the displacement of DMSO. In the second stage, the 
inoculated material is quaternized by the reaction with iodomethane or iodoethane [42]. Methoxy-modified kaolinite is used as a carrier for the adsorption of the 3-amino-1,2,4triazol herbicide known as amitrol. The methoxy modification of kaolinite is accomplished by adding methanol to the preliminarily DMSO-treated kaolinite. The adsorption of amitrol by organoclays is two times higher than its adsorption by kaolinite [43].

In another mineral of the kaolinite subgroup (halloysite), hydrogen bonds between the adjacent layers are weaker. Hence, the interlaminar adsorption of substances is possible. This mineral is also characterized by the formation of tubular aggregates provoked by the disparity of octahedral and tetrahedral sheets.

The organoclay sample obtained by the covalent bonding of halloysite with a hyperreticulated cyclodextrin grid was examined as a potential carrier for polyphenol compounds [44]. The halloysite-based organoclay was used for the adsorption of anionic pollutants from wastewaters [45]. The adsorption of phenol, 2-,3-,4-chlorphenols, 2,4dichlorphenol, and 2,4,6-trichlorphenol on the halloysite nanotubes modified with hexadecyltrimethylammonium bromide was studied [46]. According to Theng et al. (2012) [35], the application of natural halloysite, the particles of which have micro-tubular (latticed) structure, or synthetic halloysite, the particles of which can be flat or spheroidal (close to imogolite), is promising for the synthesis of clay-polymer complexes.

\subsection{Organoclays Based on 2:1 Structure Fillosilicates}

Talc and pyrophyllite are minerals with a layered crystal lattice that is responsible for their exfoliation properties in extra thin lamellas. The elasticity of these lamellas varies in different minerals because of their chemical compositions reflected in the details of the crystal lattice structure. Since charges inside lattices in the talc and pyrophyllite structure are compensated almost completely, their layers are bonded by very weak remnant Van der Waals forces. This property is responsible for the very low hardness of talc and pyrophyllite, their extremely easy splittability into elastic sheets, and the lack of tenacity in the sheets. Because of such properties, these minerals are almost never used for the synthesis of organoclays.

Nevertheless, data on the interactions of phyllosilicates of this group with various organic substances are available. For example, some researchers have studied the adsorptions of two model aromatic hydrocarbons (benzene and toluol) by talc from water. Both benzol and toluene yielded linear isotherms. The isotherm slope was steeper for toluene than for benzene, suggesting that toluene has a greater affinity to talc [47]. The rheological properties of the pyrophyllite-water suspension are different in the presence of three surface-active substances (anionic, cationic, and nonionic). The viscosity depends strongly on the type of surfactant adsorbed on the clay surface and the surface potential after adsorption. The basal reflection $\mathrm{d}_{001}$ of the pyrophyllite clay did not change after the adsorption of the surfactant, suggesting that they did not intercalate in the interlayer space [48]. The application of the pyrophyllite clay was exemplified by modifying the mineral surface based on the 3-(2-aminoethylamine) propyl-methyldimethoxysilane treatment for the subsequent adsorption $\mathrm{Pb}^{2+}$ ions from water solutions [49]. According to these authors, the modified pyrophyllite adsorbed about $93 \%$ of $\mathrm{Pb}^{2+}$ ions at the initial $\mathrm{Pb}$ concentration of $20 \mathrm{mg} / \mathrm{L}$, whereas the natural pyrophyllite only adsorbed $35 \%$ of this metal under the same conditions [49].

Clay minerals of the smectite group (montmorillonite, bentonite, beidellite, nontronite, saukonite, and saponite) are distinguished by an insignificant force of interlayer ionic bonds, strong dispersion, and intracrystal expansion. All minerals of the montmorillonite group have a low charge (0.2-0.6 units per elementary cell) due to a low degree of isomorphous ion replacement in the tetrahedral or octahedral sites, resulting in a weak electrostatic interaction between layers. The outer specific surface of smectite clays is as much as $40-70 \mathrm{~m}^{2} / \mathrm{g}$, the total specific surface is $450-850 \mathrm{~m}^{2} / \mathrm{g}[50,51]$, and the porosity is about $0.006-0.010 \mathrm{~cm}^{3} / \mathrm{g}$ [52]. The cation exchange capacity determined by the traditional methods for smectites from different deposits is $65-135 \mathrm{cmol}$ equiv $/ \mathrm{kg}$ [53]. 
The 2:1 structure phyllosilicates, with an expanding structural cell, are the main minerals used for the synthesis of organoclays [54,55]. Moreover, montmorillonite, saponite, and hectorite are the phyllosilicates most used for this purpose [27,35].

Organoclays based on bentonite are used as oil and petroleum product adsorbents [56,57], phenol and its derivatives [58,59], benzoic acid and hydroquinone [60], naphthalene and phenanthrene [61,62], and pesticides: simazine [63], methyl parathion, and tetrachlorvinphos [64], atrazine, butachlor, carbendazim, carbofuran, imidacloprid, isoproturon, pendimethalin, thiophanate- and thiamethoxam-methyl [65]. They are also used for adsorption of pharmaceutical products: amoxicillin, norfloxacine, sulfametoxazol, metoprolol, carbamazepine and trimethoprim [31], diclofenac [66,67], and industrial dyes [68].

Vermiculites, which have a higher charge than the montmorillonite group minerals (Table 2), are also expanding minerals. They, however, lack an unlimited expansion capacity, and four molecules per unit cell limit the water amount in the interlayer space. The cation exchange capacity of vermiculites is 1.5-2 times higher than that of montmorillonites, while the specific surface area (measured by the BET method) can be as much as $800 \mathrm{~m}^{2} / \mathrm{g}$ [69]. Vermiculites have a higher adsorption selectivity and an irreversible adsorption capacity in the interlayer spaces of large, weakly hydrated cations [70].

A comparison of the sorption properties of organoclays based on vermiculite and montmorillonite, modified by gemini surfactant (dichloride 2,2'-bis (dodecyldimethylammonium)ethyl ether) for the removal of Congo red dye, revealed that adsorption reached 298 and $154 \mathrm{mg} / \mathrm{kg}$, respectively, at the equilibrium state. The adsorption capacity of these organoclays depended on their hydrophobicity. The thermodynamic parameters demonstrated that the dye adsorption by the studied organoclays was an endothermic and spontaneous process [71]. Organic vermiculites, modified by hexadecyltrimethylammonium and benzyldimethyl-hexadecylamine at surfactant concentrations of $0.5,1.0$, and 2.0 of the cation exchange capacity, were used for the adsorption of anionic species in the form of As (III) and As (V). Increases in the surfactant concentration were accompanied by the morphological change of mineral grains, partial hydrophobization of the surface, deterioration of the interlayer space's structural parameters, and expansion of the interlayer space. It was noted that the studied organoclays adsorbed more As (V) than As (III). The maximum adsorption of arsenic salts took place at the maximum amount of modifiers [72].

The adsorption of Cr (VI) by montmorillonite and vermiculite, modified by hexadecylpyridinium, hexadecyltrimethylammonium, and benzethonium were studied at $\mathrm{pH}$ levels of 3-9 [73]. The interlayer space in organic vermiculites had a paraffin structure, while the organic montmorillonites had a pseudotrimolecular structure. The surface charges of clays changed from negative or positive values; they were affected strongly by the specific surface, layer charge, and $\mathrm{pH}$. Organo-vermiculites and organo-bentonites demonstrated a compatible adsorption capacity for the removal of $\mathrm{Cr}$ (VI) depending on the organic cation species. For all organoclays, the adsorbed amount of $\mathrm{Cr}$ (VI) decreased with the increase of the $\mathrm{pH}$. The influence of competing anions $\mathrm{Cl}^{-}, \mathrm{NO}_{3}{ }^{-}$, and $\mathrm{SO}_{4}{ }^{2-}$ for $\mathrm{Cr}$ (VI) adsorption turned out to be small. For the organo-vermiculites, the majority of anion adsorption centers were confined to the interlayer space.

The possibility of the intercalation of micas and, to a lesser extent, hydromicas, is limited by the high charges ( 1 in micas, 0.8 in hydromicas) located in the tetrahedral sheets, that is, immediately near the interlayer cation, which stipulates a strong electrostatic interaction of the layers and hampers a significant expansion of the interlaminar space. The experimental capacity of the cation exchange of these minerals is about 20-50 mmol equiv/100 g of mineral [26,74]. The charge of large micas (clintonites) is still higher and marked by a prominent main pattern. In the case of the bivalent interlayer cation change, the capacity of the cationic exchange of clintonites is two times higher than that of real micas. Still, such replacement is virtually impossible because of an extremely stable electrostatic bond [75]. Cation exchange in micas is a slow process because these minerals are enriched by the partly disintegrated sectors of the interlayer space (particularly in the weathered 
species), through which cations hardly diffuse [26]. The presence of such sectors (wedgeshaped zones) and their arrangement govern the selectivity of cation exchange. Large hydrated inorganic cations, such as $\mathrm{Ca}^{2+}$ and $\mathrm{Mg}^{2+}$, and organic cations, cannot enter these zones, particularly if they are located not only at the edges of interlayer space but also inside it [26].

When muscovite intercalates with ammonium salts, changes in the volume unit cell of the mineral are negligible during the interlayer $\mathrm{K}^{+}$exchange into $\mathrm{NH}_{4}{ }^{+}$ions. Still, a $4 \%$ expansion was observed when $\mathrm{K}^{+}$was exchanged for methylammonium $\mathrm{CH}_{3} \mathrm{NH}_{3}{ }^{+}$[76].

More complicated modification methods were proposed because of the difficulty of direct intercalation to micas. Previously, different research groups $[77,78]$ used Li and cations of alkali earth metals $\left(\mathrm{Ba}^{2+}, \mathrm{Ca}^{2+}\right.$, and $\left.\mathrm{Mg}^{2+}\right)$ to change the structure for the first stage of the ion exchange processing of muscovite. However, an efficient method-the treatment of muscovite with melted lithium nitrate at $350{ }^{\circ} \mathrm{C}$ for $12 \mathrm{~h}$-for alleviating the subsequent intercalation by organic substances was only proposed in 2005 [79]. Thus, the specific surface of muscovite increased from 3.5 to $170 \mathrm{~m}^{2} / \mathrm{g}$. The reaction with the nitrates of some other alkali metals did not lead to an appreciable increase of the specific surface.

Weng-Lip et al. [80] accomplished the intercalation of muscovite cations of cetyltrimethylammonium bromide with the two-stage method, including, at first, the melting of the mineral with lithium nitrate at $300^{\circ} \mathrm{C}$ and then, at the second stage, interaction with the organic substance solution in an autoclave at $180^{\circ} \mathrm{C}$. Fourier transform infrared spectroscopy showed that cetyltrimethylammonium cations diffuse into the aluminosilicate laminas and make up a stable electrostatic bond with the clay surface. In addition, the intercalated chains of organic cation are distributed uniformly to make up the paraffin-type structures in the muscovite clay.

Hydromicas are distinguished from micas by the abundance of easily removable bonded water and fewer cations making up the interlayer bonds. Therefore, organoclays based on them are more widespread. The adsorption of nonionic organic compounds (benzene, toluol, ethylbenzene, propylbenzene, butylbenzene, t-butylbenzene, naphthalene, and diphenyl) by organoclays was studied based on several phyllosilicates, including illite intercalated with hexadecyltrimethylammonium [81]. The sorption of the pesticide paraquat by illite, bentonite, and sepiolite, as well as organoclays based on them, was studied [82]. Illite demonstrated the highest values of the maximum paraquat adsorption among the minerals under consideration. When it was modified with nonylammonium chloride, the maximum paraquat adsorption increased by not more than $10 \%$, and it decreased with modification with dodecylammonium chloride [82]. The researchers examined the sorption of illite modified with hexadecyltrimethylammonium, 1,2-dichlorbenzene, 1,3-dichlorbenzene, and 1,4-dichlorbenzene [83]. Glauconite modified by stearic acid was used as an adsorbent for the adsorption of oil and oil products [84].

\subsection{The Possibility of Using 2:1:1 Structure Phyllosilicates for the Synthesis of Organoclays}

Chlorites are typical 2:1:1-structured phyllosilicates. Owing to the presence of an additional octahedral sheet between the three-layer structures, unweathered chlorite group minerals lack a chemically active internal surface and an interlayer sorption capacity. Chlorites have low values of CEC and specific surface area $\left(26-45 \mathrm{~m}^{2} / \mathrm{g}\right)$ [85].

Information about the synthesis of organoclays from chlorites is virtually absent. Indirect data, however, suggest the possibility of this process. Researchers studied the adsorption of soluble intracellular components of four phytoplankton species (Phaeocystis globosa, Gymnodinium sanguineum, Scrippsiella trochoidea, and Ditylum brightwellii) on three minerals (montmorillonite, kaolinite, and chlorite), and chlorite demonstrated high sorption efficiency [86]. Chlorite and illite adsorbed the macrolide antibiotic azithromycin and the chinoline antibiotic levofloxacin efficiently [87]. The cationic surfactant (cetyltrimethylammonium bromide) was used successfully for the synthesis of organophilic material based on a clay sample composed of smectite $(26 \%)$, chlorite $(20 \%)$, illite $(17 \%)$, and kaolinite $(14 \%)$ [88]. 


\subsection{Organoclays Based on Other Silicates (Close to Inosilicates)}

The construction of the crystal lattice of minerals of the palygorskite and sepiolite groups is based on 2:1 and extended in one basal dimension. A chain of octahedra is sandwiched between tetrahedral apices facing each other. Sepiolite is distinguished from palygorskite by a slightly wider chain. Individual chains are also joined with each other via common apices of some tetrahedra occupying edge positions in the chains. Thus, the structure includes channels that are extended parallel to the chains, resulting in internal surface formation [85]. The capacity of sepiolite cation exchange is 20-30 mmol equiv/100 $\mathrm{g}$ [89], and the fibrous structure of clay does not expand with the addition of water or organic solvents. Palygorskite and sepiolite comprise long fibers (several micrometers long and 10-30 $\mathrm{nm}$ wide) with channels extended parallel to the fiber length [34]. A review of the sepiolite-based organic nanocomposites was published recently [89].

Organoclays based on Australian palygorskite, modified by cationic surfactants (different doses of octadecyltrimethylammonium bromide, and dioctadecyldimethylammonium bromide), was used for the adsorption of herbicide from synthetic auxin groups (2,4dichlorophenoxyacetic acid). Molecules of the surfactant were fixed to the surface of the rod-shaped mineral crystals to weaken the interactions between monocrystals [90]. The application of organoclays based on smectite and attapulgite to bind endotoxins demonstrated high efficiency in a water solution [91]. Palygorskite modified with quaternary ammonium salt was used to remove oil from emulsions [92].

\section{Conclusions}

Organoclays are effective adsorbents, prepared by intercalation or surface grafting of clays and clay minerals with various organic compounds. Organoclays have important practical applications as adsorbents of a wide range of organic pollutants and some inorganic contaminants.

The traditional raw materials for the synthesis of organoclays are 2:1-structured phyllosilicates with the expanding structural cell of the smectite (montmorillonite) group. Montmorillonite, saponite, and hectorite are the phyllosilicates most used for this purpose. Organoclays based on the minerals of the smectite group are used as adsorbents of oil and oil products, phenol and its derivatives, benzoic acid and hydroquinone, naphthalene and phenanthrene, pesticides, pharmaceutical products, industrial dyes, and so forth.

In addition, raw materials for organoclay production can be represented by layered silicates of other groups, for example, 1:1, 2:1, and 2:1:1-structured phyllosilicates and other silicates such as palygorskite and sepiolite (close to chain inosilicates). The structural characteristics, including expandability and structural charge, of various groups of phyllosilicates and inosilicates affect their ability to be modified by organic surfactants as well as the adsorption properties of organoclays for various pollutants. Based on clay minerals with different abilities to expand their structure, adsorption materials with specified properties, such as adsorption capacity to the required capacity, stability, and being safe for the environment, can be obtained.

Author Contributions: Conceptualization, L.P., S.M. and T.M.; resources, I.P. and T.B.; data curation, T.M.; writing —original draft preparation, L.P., T.M. and S.M.; writing—review and editing, Y.A. and D.P.; visualization, I.P. and A.B.; supervision, L.P. and S.M.; project administration, S.M.; funding acquisition, Y.A. and T.M. All authors have read and agreed to the published version of the manuscript.

Funding: This research was funded by a grant from the Government of the Tula Region in 2020 in the field of science and technology (Agreement no. DC/170 from 29.10.2020) and the Russian Foundation for Basic Research, grant nos. 19-29-05265 mk, 19-34-60041 and 19-34-90185.

Data Availability Statement: The data is contained within the article.

Conflicts of Interest: The authors declare there are no competing interests. 


\section{References}

1. Churchman, G.J.; Gates, W.P.; Theng, B.K.G.; Yuan, G. Clays and clay minerals for pollution control. In Handbook of Clay Science; Elsevier: Amsterdam, The Netherlands, 2013; pp. 625-675.

2. Srinivasan, R. Advances in Application of Natural Clay and Its Composites in Removal of Biological, Organic, and Inorganic Contaminants from Drinking Water. Adv. Mater. Sci. Eng. 2011, 2011, 1-17. [CrossRef]

3. Sarkar, B.; Rusmin, R.; Ugochukwu, U.C.; Mukhopadhyay, R.; Manjaiah, K.M. Modified clay minerals for environmental applications. In Modified Clay and Zeolite Nanocomposite Materials: Environmental and Pharmaceutical Applications; Mercurio, M., Sarkar, B., Langella, A., Eds.; Elsevier: Amsterdam, The Netherlands, 2019; pp. 113-127.

4. United States Geological Survey. National Minerals Information Center. Clays Statistics and Information. Annual Publications. Mineral Commodity Summaries. 2021. Available online: https://pubs.usgs.gov/periodicals/mcs2021/mcs2021-clays.pdf (accessed on 1 January 2021).

5. Bailey, S.E.; Olin, T.J.; Bricka, R.; Adrian, D. A review of potentially low-cost sorbents for heavy metals. Water Res. 1999, 33, 2469-2479. [CrossRef]

6. Babel, S.; Kurniawan, T.A. Low-cost adsorbents for heavy metals uptake from contaminated water: A review. J. Hazard. Mater. 2003, 97, 219-243. [CrossRef]

7. Borchardt, G. Smectites. In Minerals in Soil Environments, 2nd ed.; Dixon, J.B., Weed, S.B., Eds.; SSSA Book Series; Soil Science Society of America: Madison, WI, USA, 1989; pp. 675-727.

8. Dixon, J.B. Kaolin and Serpentine Group Minerals. Methods Soil Anal. Part Mineral. Methods 2018, 467-525. [CrossRef]

9. Dehmani, Y.; Ed-Dra, A.; Zennouhi, O.; Bouymajane, A.; Rhazi Filali, F.; Nassiri, L.; Abouarnadasse, S. Chemical character-ization and adsorption of oil mill wastewater on Moroccan clay in order to be used in the agricultural field. Heliyon 2020, 6, e03164. [CrossRef] [PubMed]

10. He, H.; Ma, L.; Zhu, J.; Frost, R.L.; Theng, B.K.; Bergaya, F. Synthesis of organoclays: A critical review and some unresolved issues. Appl. Clay Sci. 2014, 100, 22-28. [CrossRef]

11. Bergaya, F.; Lagaly, G. Chapter 1. General introduction: Clays, clay minerals and clay science. In Developments in Clay Science; Bergaya, F., Lagaly, G., Eds.; Elsevier: Amsterdam, The Netherlands, 2013; Volume 5A, pp. 1-19.

12. Theng, B.K.G.; Churchman, G.J.; Gates, W.P.; Yuan, G. Organically modified clays for pollutant uptake and environmental protection. In Soil Mineral-Microbe-Organic Interactions: Theories and Applications; Huang, Q., Huang, P.M., Violante, A., Eds.; Springer: Berlin, Germany, 2008; pp. 145-174.

13. Theng, B.K.G. Formation and Properties of Clay-Polymer Complexes, 2nd ed.; Elsevier: Amsterdam, The Netherlands, 2012; 526p.

14. Guégan, R.; Veron, E.; Le Forestier, L.; Ogawa, M.; Cadars, S. Structure and Dynamics of Nonionic Surfactant Aggregates in Layered Materials. Langmuir 2017, 33, 9759-9771. [CrossRef]

15. Barrer, R.M.; MacLeod, D.M. Intercalation and sorption by montmorillonite. Trans. Faraday Soc. 1954, 50, 980-989. [CrossRef]

16. Barrer, R.M.; MacLeod, D.M. Activation of montmorillonite by ion exchange and sorption complexes of tetra-alkyl ammonium montmorillonites. Trans. Faraday Soc. 1955, 51, 1290-1300. [CrossRef]

17. Guégan, R. Organoclay applications and limits in the environment. Comptes Rendus Chim. 2019, 22, 132-141. [CrossRef]

18. Lagaly, G.; Ogawa, M.; Dékány, I. Clay mineral-organic interactions. In Handbook of Clay Science. Developments in Clay Science; Bergaya, F., Lagaly., G., Eds.; Elsevier: Amsterdam, The Netherlands, 2013; Volume 5, pp. 435-505.

19. Brixie, J.M.; Boyd, S.A. Treatment of Contaminated Soils with Organoclays to Reduce Leachable Pentachlorophenol. J. Environ. Qual. 1994, 23, 1283-1290. [CrossRef]

20. Boeva, N.M.; Bocharnikova, Y.I.; Nasedkin, V.V.; Belousov, P.E.; Demidenok, K.V. Thermal analysis as an express method for assessing the quality and quantity of natural and synthesized organoclays. Nanotechnologies Russ. 2013, 8, 205-208. [CrossRef]

21. Lagaly, G. Layer charge determination by alkylammonium ions. In Clay Minerals Society Workshop Lectures: Layer Charge Characteristics of 2:1 Silicate Clay Minerals; Mermut, A.R., Ed.; The Clay Minerals Society: Boulder, CO, USA, 1994; Volume 6, pp. $1-46$.

22. Lee, S.Y.; Kim, S.J. Expansion characteristics of organoclay as a precursor to nanocomposites. Colloids Surfaces A Physicochem. Eng. Asp. 2002, 211, 19-26. [CrossRef]

23. Churakov, S.V. Ab initio study of edge sites reactivity on pyrophyllite. In Proceedings of the International Meeting "Clays in Natural \& Engineered Barriers for Radioactive Waste Confinement", Tours, France, 14-18 March 2005; pp. $219-220$.

24. Popov, V.G.; Abdrakhmanov, R.F. Ion Exchange Concept in Genetic Hydrogeochemistry; Gilem, Bashkir Encyclopedia: Ufa, Russia, 2013; 356p. (In Russian)

25. Civan, F. Reservoir Formation Damage: Fundamentals, Modeling, Assessment, and Mitigation, 3rd ed.; Gulf Professional Publishing: Houston, TX, USA, 2015; 1042p.

26. Sparks, D.L. Environmental Soil Chemistry; Elsevier: Amsterdam, The Netherlands, 2003; 352p.

27. Ray, S.S. Introduction to environmentally friendly polymer nanocomposites. In Environmentally Friendly Polymer Nanocomposites, Types, Processing and Properties, 1st ed.; Woodhead Publishing: Sawston, UK, 2013; pp. 3-24.

28. Brindley, G.W. Ethylene glycol and glycerol complexes of smectites and vermiculites. Clay Miner. 1966, 6, 237-259. [CrossRef]

29. Cloos, P.; Laura, R.D.; Badot, C. Adsorption of ethylene diamine on montmorillonite saturated with different cations-V: Ammonium- and triethylammonium-montmorillonite: Ion exchange, protonation and hydrogen-bonding. Clays Clay Miner. 1975, 23, 417-423. [CrossRef] 
30. Farmer, V.C.; Mortland, M.M. An infrared study of the co-ordination of pyridine and water to exchangeable cations in montmorillonite and saponite. J. Chem. Soc. A 1966, 344-351. [CrossRef]

31. Guégan, R.; De Oliveira, T.; Le Gleuher, J.; Sugahara, Y. Tuning down the environmental interests of organoclays for emerging pollutants: Pharmaceuticals in presence of electrolytes. Chemosphere 2020, 239, 124730. [CrossRef]

32. Kowalska, M.; Güler, H.; Cocke, D.L. Interactions of clay minerals with organic pollutants. Sci. Total. Environ. 1994, 141, 223-240. [CrossRef]

33. Gerasin, V.A.; Antipov, E.M.; Karbushev, V.V.; Kulichikhin, V.; Karpacheva, G.P.; Talroze, R.V.; Kudryavtsev, Y.V. New approaches to the development of hybrid nanocomposites: From structural materials to high-tech applications. Russ. Chem. Rev. 2013, 82, 303-332. [CrossRef]

34. Brindley, G.W.; Moll, W.F. Complexes of natural and synthetic Ca-montmorillonites with fatty acids. Am. Mineral. 1965, 50, 1355-1370.

35. Theng, B.K.G. Polymer-clay nanocomposites. In Developments in Clay Science; Theng, B.K.G., Ed.; Elsevier: Amsterdam, The Netherlands, 2012; Volume 4, pp. 201-241.

36. He, H.; Ma, Y.; Zhu, J.; Yuan, P.; Qing, Y. Organoclays prepared from montmorillonites with different cation exchange capacity and surfactant configuration. Appl. Clay Sci. 2010, 48, 67-72. [CrossRef]

37. Gougeon, R.D.; Soulard, M.; Reinholdt, M.; Miehé-Brendlé, J.; Chézeau, J.-M.; Le Dred, R.; Marchal, R.; Jeandet, P. Polypeptide Adsorption on a Synthetic Montmorillonite: A Combined Solid-State NMR Spectroscopy, X-ray Diffraction, Thermal Analysis and N2 Adsorption Study. Eur. J. Inorg. Chem. 2003, 2003, 1366-1372. [CrossRef]

38. Lagaly, G. Interaction of alkylamines with different types of layered compounds. Solid State Ionics 1986, 22, 43-51. [CrossRef]

39. Wang, A.; Wang, W. Introduction. In Nanomaterials from Clay Minerals. A New Approach to Green Functional Materials, 1st ed.; Wang, A., Wang, W., Eds.; Elsevier: Amsterdam, The Netherlands, 2019; pp. 1-20.

40. Rahromostaqim, M.; Sahimi, M. Molecular Dynamics Study of the Effect of Layer Charge and Interlayer Cations on Swelling of Mixed-Layer Chlorite-Montmorillonite Clays. J. Phys. Chem. C 2020, 124, 2553-2561. [CrossRef]

41. Kumar, A.; Lingfa, P. Sodium bentonite and kaolin clays: Comparative study on their FT-IR, XRF, and XRD. Mater. Today Proc. 2020, 22, 737-742. [CrossRef]

42. Letaief, S.; Detellier, C. Functionalization of the interlayer surfaces of kaolinite by alkylammonium groups from ionic liquids. Clays Clay Miner. 2009, 57, 638-648. [CrossRef]

43. Tan, D.; Yuan, P.; Annabi-Bergaya, F.; Liu, D.; He, H. Methoxy-modified kaolinite as a novel carrier for high-capacity loading and controlled-release of the herbicide amitrole. Sci. Rep. 2015, 5, srep08870. [CrossRef]

44. Massaro, M.; Riela, S. Organo-clay nanomaterials based on halloysite and cyclodextrin as carriers for polyphenolic compounds. J. Funct. Biomater. 2018, 9, 61. [CrossRef]

45. Xi, Y.; Mallavarapu, M.; Naidu, R. Preparation, characterization of surfactants modified clay minerals and nitrate adsorption. Appl. Clay Sci. 2010, 48, 92-96. [CrossRef]

46. Słomkiewicz, P.; Szczepanik, B.; Czaplicka, M. Adsorption of Phenol and Chlorophenols by HDTMA Modified Halloysite Nanotubes. Materials 2020, 13, 3309. [CrossRef]

47. Hashizume, H. Adsorption of aromatic compounds in water by talc. Clay Sci. 2009, 14, 61-64.

48. Desai, H.; Biswal, N.R.; Paria, S. Rheological behavior of pyrophyllite-water slurry in the presence of anionic, cationic, and nonionic surfactants. Ind. Eng. Chem. Res. 2010, 49, 5400-5406. [CrossRef]

49. Erdemoğlu, M.; Sayılkan, F.; Akarsu, M.; Şener, Ş. Organo-functional modified pyrophyllite: Preparation, characterisation and $\mathrm{Pb}$ (II) ion adsorption property. Appl. Clay Sci. 2004, 27, 41-52. [CrossRef]

50. Osipov, V.I.; Sokolov, V.N.; Rumyantseva, N.A. Microstructure of Clay Rocks; Nedra: Moscow, Russia, 1989; 211p. (In Russian)

51. Pokidko, B.V.; Bukanova, E.F.; Tutorsky, I.A.; Il'ina, M.B. Influence of Ca2+ on the adsorption of different surfactants in the bentonite-water interface. Rev. MITHT 2009, 4, 77-83. (In Russia)

52. Fetter, G.; Bosch, P. Microwave effect on clay pillaring. In Pillared Clays and Related Catalysts; Gil, A., Korili, S.A., Trujillano, R., Vicente, M.A., Eds.; Springer: New York, NY, USA, 2010; pp. 1-21.

53. Ammann, L.; Bergaya, F.; Lagaly, G. Determination of the cation exchange capacity of clays with copper complexes revisited. Clay Miner. 2005, 40, 441-453. [CrossRef]

54. Madejová, J.; Barlog, M.; Jankovič, Ĺ.; Slaný, M.; Pálková, H. Comparative study of alkylammonium- and alkylphosphoniumbased analogues of organo-montmorillonites. Appl. Clay Sci. 2021, 200, 105894. [CrossRef]

55. Slaný, M.; Jankovič, L'.; Madejová, J. Structural characterization of organo-montmorillonites prepared from a series of primary alkylamines salts: Mid-IR and near-IR study. Appl. Clay Sci. 2019, 176, 11-20. [CrossRef]

56. Mohamed, A.I.A.; Hussein, I.A.; Sultan, A.S.; Al-Muntasheri, G.A. Use of organoclay as a stabilizer for water-in-oil emulsions under high-temperature high-salinity conditions. J. Petrol. Sci. Eng. 2018, 160, 302-312. [CrossRef]

57. Moazed, H.; Viraraghavan, T. Removal of Oil from Water by Bentonite Organoclay. J. Hazard. Toxic Radioact. Waste 2005, 9 , 130-134. [CrossRef]

58. Nafees, M.; Waseem, A. Organoclays as Sorbent Material for Phenolic Compounds: A Review. CLEAN Soil Air Water 2014, 42, 1500-1508. [CrossRef]

59. Li, Z.; Yao, M.; Lin, J.; Yang, B.; Zhang, X.; Lei, L. Pentachlorophenol sorption in the cetyltrimethylammonium bro-mide/bentonite one-step process in single and multiple solute systems. J. Chem. Eng. Data 2013, 58, 2610-2615. [CrossRef] 
60. Yıldız, N.; Gönülşen, R.; Koyuncu, H.; Çalımlı, A. Adsorption of benzoic acid and hydroquinone by organically modified bentonites. Colloids Surfaces A Physicochem. Eng. Asp. 2005, 260, 87-94. [CrossRef]

61. Changchaivong, S.; Khaodhiar, S. Adsorption of naphthalene and phenanthrene on dodecylpyridinium-modified bentonite. Appl. Clay Sci. 2009, 43, 317-321. [CrossRef]

62. Xu, L.; Zhang, M.; Zhu, L. Adsorption-desorption behavior of naphthalene onto CDMBA modified bentonite: Contribution of the $\pi-\pi$ interaction. Appl. Clay Sci 2014, 100, 29-34. [CrossRef]

63. Cruz-Guzmán, M.; Celis, R.; Hermosín, M.C.; Cornejo, J. Adsorption of the Herbicide Simazine by Montmorillonite Modified with Natural Organic Cations. Environ. Sci. Technol. 2003, 38, 180-186. [CrossRef] [PubMed]

64. El-Nahhal, Y.; Undabeytia, T.; Polubesova, T.; Mishael, Y.G.; Nir, S.; Rubin, B. Organo-clay formulations of pesticides: Reduced leaching and photodegradation. Appl. Clay Sci. 2001, 18, 309-326. [CrossRef]

65. Narayanan, N.; Gajbhiye, V.T.; Gupta, S.; Manjaiah, K.M. Novel biopolymer-nano-organoclay composites for the decontam-ination of pesticides from water. Pestic. Res. J. 2016, 28, 25-34.

66. De Oliveira, T.; Guégan, R.; Thiebault, T.; Le Milbeau, C.; Muller, F.; Teixeira, V.; Giovanela, M.; Boussafir, M. Adsorption of diclofenac onto organoclays: Effects of surfactant and environmental ( $\mathrm{pH}$ and temperature) conditions. J. Hazard. Mater. 2017, 323 Pt A, 558-566. [CrossRef]

67. França, D.B.; Trigueiro, P.; Filho, E.C.S.; Fonseca, M.G.; Jaber, M. Monitoring diclofenac adsorption by organophilic alkylpyridinium bentonites. Chemosphere 2020, 242, 125109. [CrossRef]

68. Huang, P.; Kazlauciunas, A.; Menzel, R.; Lin, L. Determining the Mechanism and Efficiency of Industrial Dye Adsorption through Facile Structural Control of Organo-montmorillonite Adsorbents. ACS Appl. Mater. Interfaces 2017, 9, 26383-26391. [CrossRef]

69. Huggett, J.M. Clay Minerals. In Reference Module in Earth Systems and Environmental Sciences; Elsevier: Amsterdam, The Netherlands, 2015.

70. Trofimov, S.Y.; Sokolova, T.A.; Dronova, T.Y.; Tolpeshta, I.I. Mineral Components of Soils; Grif and K.: Tula, Russia, 2007; 104p. (In Russian)

71. Ding, F.; Gao, M.; Shen, T.; Zeng, H.; Xiang, Y. Comparative study of organo-vermiculite, organo-montmorillonite and or-ganosilica nanosheets functionalized by an ether-spacer-containing Gemini surfactant: Congo red adsorption and wettability. Chem. Eng. J. 2018, 349, 388-396. [CrossRef]

72. Tuchowska, M.; Wołowiec, M.; Solińska, A.; Kościelniak, A.; Bajda, T. Organo-Modified Vermiculite: Preparation, Characterization, and Sorption of Arsenic Compounds. Minerals 2019, 9, 483. [CrossRef]

73. Dultz, S.; An, J.-H.; Riebe, B. Organic cation exchanged montmorillonite and vermiculite as adsorbents for Cr(VI): Effect of layer charge on adsorption properties. Appl. Clay Sci. 2012, 67-68, 125-133. [CrossRef]

74. Osman, M.A.; Suter, U.W. Determination of the Cation-Exchange Capacity of Muscovite Mica. J. Colloid Interface Sci. 2000, 224, 112-115. [CrossRef] [PubMed]

75. Ravella, R. Swelling Mica-Type Clays of Variable Charge: Synthesis, Characterization and Ion Exchange Studies. Ph.D. Thesis, The Pennsylvania State University, University Park, PA, USA, 2006; 163p.

76. Yu, C.J.; Choe, S.H.; Jang, Y.M.; Jang, G.H.; Pae, Y.H. First-principles study of organically modified muscovite mica with ammonium (NH4+) or methylammonium (CH3NH3+) ion. J. Mater. Sci. 2016, 51, 10806-10818. [CrossRef]

77. Bracke, G.; Satir, M.; Krauss, P. The Cryptand [222] for exchanging cations of micas. Clays Clay Miner. 1995, 43, 732-737. [CrossRef]

78. Shimizu, K.-I.; Hasegawa, K.; Nakamuro, Y.; Kodama, T.; Komarneni, S. Alkaline earth cation exchange with novel Na-3-mica: Kinetics and thermodynamic selectivities. J. Mater. Chem. 2004, 14, 1031-1035. [CrossRef]

79. Zhao, L.Y.; Wang, X.K.; Wu, N.Z.; Xie, Y.C. Cleaving of muscovite powder by molten lithium nitrate. Colloid Polym. Sci. 2005, 283, 699-702. [CrossRef]

80. Weng-Lip, L.; Salleh, N.M.; Abdul Rahman, N.A.; Bakhtiar, N.S.A.A.; Akil, H.M.; Zubir, S.A. Enhanced intercalation of organomuscovite prepared via hydrothermal reaction at low temperature. Bull. Mater. Sci. 2019, 42, 242. [CrossRef]

81. Jaynes, W.; Boyd, S. Clay Mineral Type and Organic Compound Sorption by Hexadecyltrimethlyammonium-Exchanged Clays. Soil Sci. Soc. Am. J. 1991, 55, 43-48. [CrossRef]

82. Seki, Y.; Yurdakoç, K. Paraquat adsorption onto clays and organoclays from aqueous solution. J. Colloid. Interface Sci. 2005, 287, 1-5. [CrossRef] [PubMed]

83. Sheng, G.; Boyd, S.A. Polarity effect on dichlorobenzene sorption by hexadecyltrimethylammonium-exchanged clays. Clays Clay Miner. 2000, 48, 43-50. [CrossRef]

84. Peregudov, Y.S.; Mejri, R.; Gorbunova, E.M.; Niftaliev, S.I. Glauconite-based sorbents for skimming oil and oil products. Condens. Matter Interph. 2020, 22, 257-265. (In Russian)

85. Scriabina, O.A. Mineralogical Composition of Soils and Parent Rocks; Publishing House of "Perm State Agricultural Academy": Perm, Russia, 2010; 120p. (In Russian)

86. Satterberg, J.; Arnarson, T.S.; Lessard, E.J.; Keil, R.G. Sorption of organic matter from four phytoplankton species to montmorillonite, chlorite and kaolinite in seawater. Mar. Chem. 2003, 81, 11-18. [CrossRef]

87. Hanamoto, S.; Ogawa, F. Predicting the sorption of azithromycin and levofloxacin to sediments from mineral and organic components. Environ. Pollut. 2019, 255, 113180. [CrossRef] [PubMed] 
88. Acikyildiz, M.; Gurses, A.; Yolcu, H.H. Synthesis of super hydrophobic clay by solution intercalation method from aqueous dispersions. In Acta Physica Polonica A, Proceedings of the 4th International Congress APMAS2014, Fethiye, Turkey, 24-27 April 2014; Institute of Physics, Polish Academy of Sciences: Warsaw, Poland, 2015; Volume 127, pp. 1156-1160.

89. Zaini, N.A.M.; Ismail, H.; Rusli, A. Short Review on Sepiolite-Filled Polymer Nanocomposites. Polym. Technol. Eng. 2017, 56, 1665-1679. [CrossRef]

90. Xi, Y.; Mallavarapu, M.; Naidu, R. Adsorption of the herbicide 2,4-D on organo-palygorskite. Appl. Clay Sci. 2010, 49, 255-261. [CrossRef]

91. Schaumberger, S.; Ladinig, A.; Reisinger, N.; Ritzmann, M.; Schatzmayr, G. Evaluation of the endotoxin binding efficiency of clay minerals using the Limulus Amebocyte lysate test: An in vitro study. AMB Express 2014, 4, 1. [CrossRef]

92. Silva, V.C.; Batista, T.S.; Ramos, I.B.M.; Barros, T.R.B.; De Sousa, B.V. Organophilization Process and Characterization of Palygorskite Clay (Attapulgite). Mater. Sci. Forum 2016, 881, 218-223. [CrossRef] 